\title{
Using nekton growth as a metric for assessing habitat restoration by marsh terracing
}

\author{
Lawrence P. Rozas ${ }^{1, *}$, Thomas J. Minello ${ }^{2}$ \\ ${ }^{1}$ NOAA Fisheries Service, Estuarine Habitats and Coastal Fisheries Center, 646 Cajundome Boulevard, Lafayette, \\ Louisiana 70506, USA \\ ${ }^{2}$ National Marine Fisheries Service, Galveston Laboratory, 4700 Avenue U, Galveston, Texas 77551, USA
}

\begin{abstract}
We conducted field growth experiments to evaluate marsh-terracing restoration in Galveston Bay, Texas (USA). Growth rates were compared for selected species held in mesocosms for $\sim 7 \mathrm{~d}$ within 4 habitat type treatments: terrace marsh edge (TerM), terrace pond (TerP), reference marsh edge (RefM), and reference pond (RefP). Environmental variables were measured during each experiment, and values measured inside the experimental mesocosms generally tracked outside values. Mean daily growth rates were 0.7 to $1.9 \mathrm{~mm}$ (30 to $143 \mathrm{mg}$ ) for brown shrimp Farfantepenaeus aztecus, 0.4 to $1.2 \mathrm{~mm}$ (8 to $67 \mathrm{mg}$ ) for white shrimp Litopenaeus setiferus, 0.3 to $0.6 \mathrm{~mm}$ (15 to 194 $\mathrm{mg}$ ) for blue crab Callinectes sapidus, and 0.1 to $0.4 \mathrm{~mm}(0.3$ to $3 \mathrm{mg})$ for daggerblade grass shrimp Palaemonetes pugio. No difference was detected in growth rates among treatments for blue crab and daggerblade grass shrimp. White shrimp growth rates in August 2002 were higher in TerP than RefP, and in October 2002, were higher in RefP than TerM. Brown shrimp grew more rapidly in RefM than TerM in early May 2003, but mean growth rates were similar in both habitat types later in May 2003, and significantly lower than growth rates in RefP and TerP. Even though growth rates were not consistently higher in terrace habitat types, production rates may be higher in terrace fields than over shallow non-vegetated bottom (the habitat type replaced by marsh terracing); much higher densities of fishery species in terrace habitats more than compensate for occasionally lower growth rates there. However, our production rates should be used cautiously, because we did not include mortality rates in these estimates. We recommend using a combination of different metrics, including mortality rate, to assess secondary productivity of marsh terracing or other restoration projects.
\end{abstract}

KEY WORDS: Growth $\cdot$ Penaeid shrimp $\cdot$ Field experiment $\cdot$ Marsh terracing $\cdot$ Restoration

\section{INTRODUCTION}

Marsh terracing has been used to restore habitat for fishery species at numerous sites in Louisiana and Texas (USA) since 1990 (Underwood et al. 1991, Turner \& Streever 2002). Terraces constructed from excavated bottom sediments replace shallow nonvegetated bottom (SNB) with intertidal marsh, and are commonly arranged in a checkerboard pattern of square cells with open corners (Rozas \& Minello 2001).

Marsh terracing appears to restore some degree of fishery habitat function to degraded marshes based on comparisons of nekton densities and standing crops in terracing projects and nearby reference areas (Rozas \& Minello 2001, Bush Thom et al. 2004, Gossman 2005, Rozas et al. 2005, La Peyre et al. 2007, Rozas \& Minello 2007); few studies have incorporated metrics other than nekton abundance and biomass to assess marsh terrace functions. La Peyre et al. (2007) used fish species composition and condition to evaluate habitat quality in shallow ponds created by marsh terracing. Based on differences in nekton assemblages between terrace and reference ponds and poorer condition in terrace ponds for 2 of the 6 fish species tested, they concluded that terrace ponds lacked functional equivalency with natural marsh ponds. 
The growth rate of fishery species can be used as a metric for quantifying the habitat function of food resource supply, and this metric may be a more direct measure than quantity and quality of available food in a habitat. Habitat-specific growth rates have been used to measure and compare this food-provision function among estuarine habitats (Minello \& Zimmerman 1991, Sogard 1992, Rooker et al. 1999, Phelan et al. 2000, Stunz et al. 2002), and growth rate is one of the metrics recommended for identifying primary nursery areas for fishery species (Minello 1999, Beck et al. 2001, Minello et al. 2003).

Presumably growth is faster at sites that provide more and better quality food, and rapid growth rates confer several advantages to the young of fishery species. Mortality rates are inversely related to size; therefore, increased growth rates should increase the overall probability of survival by reducing the period an organism is most vulnerable to predators (Sogard 1992, Levin et al. 1997, Stunz et al. 2002). Rapid growth rates also may improve individual fitness by enabling an animal to reach maturity more quickly and at a larger size. For example, fecundity in fishes increases with female size (Bagenal 1978, Moyle \& Cech 1982). High growth rates for individuals can also have significant population-level benefits by increasing the rate of recruitment to adult populations (Houde 1987). Even relatively small increases in growth rates of early life stages may significantly increase the numbers of individuals surviving to adulthood (Houde 1989).

Multiple metrics are required to completely assess the habitat function of marsh terracing and other restoration techniques. Information on growth and survival rates for fishery species would be especially useful because it can be used with density and biomass data to estimate fishery productivity; estimates of productivity may provide the best indicator of habitat value.

Our research objective was to evaluate marsh terracing as a method for restoring estuarine habitat and fishery production in Galveston Bay, Texas (USA), by comparing growth rates of selected species between a marsh terrace field and a nearby reference area. We tested the null hypothesis that short-term (7 d) growth rates of experimental animals were similar among 4 habitat treatments: terrace marsh, reference marsh, terrace pond, and reference pond.

\section{MATERIALS AND METHODS}

Our study area was located within Galveston Island State Park (GISP) in Carancahua Cove on the upper Texas coast $\left(29^{\circ} 12^{\prime} \mathrm{N}, 94^{\circ} 58^{\prime} \mathrm{W}\right)$. The park is located on West Bay, a polyhaline water body of the Galveston
Bay estuary. West Bay is microtidal, and tides in the study area are predominantly diurnal with a mean daily range of $0.3 \mathrm{~m}$ (Orlando et al. 1991). The study area included terrace fields constructed in the spring and summer of 1999 to restore intertidal wetlands converted to open water in the latter half of the 20th century (Rozas \& Minello 2007). Following construction, terrace ridges were planted with Spartina alterniflora Loisel. in summer 1999. All experiments were carried out inside 2 terrace fields, a $120 \times 360 \mathrm{~m}$ terrace field located along the western shore of Carancahua Cove, and a $180 \times 180 \mathrm{~m}$ terrace field on the southwestern shore of this cove; a reference area located between and adjacent to these 2 terrace fields was also used (see Fig. 1 in Rozas \& Minello 2007). The 9.3 ha reference area was a mixture of natural $S$. alterniflora marsh and SNB.

We conducted growth experiments using decapod crustaceans held in field mesocosms placed at randomly selected locations inside the 2 terrace fields and reference area. Mesocosms were bottomless fiberglass cylinders $(1.14 \mathrm{~m}$ in diameter, and $1.5 \mathrm{~m}$ or $1.8 \mathrm{~m}$ tall; Fig. 1) that enclosed $1 \mathrm{~m}^{2}$ of habitat (emergent marsh vegetation or pond). Three ports $(10 \times 10 \mathrm{~cm})$, evenly spaced around each cylinder and covered by a $2 \mathrm{~mm}$ mesh screen, allowed exchange of water between mesocosm and the outside environment. The bottom of each port opening was located $30 \mathrm{~cm}$ above the bottom edge of the mesocosm. When the mesocosm was

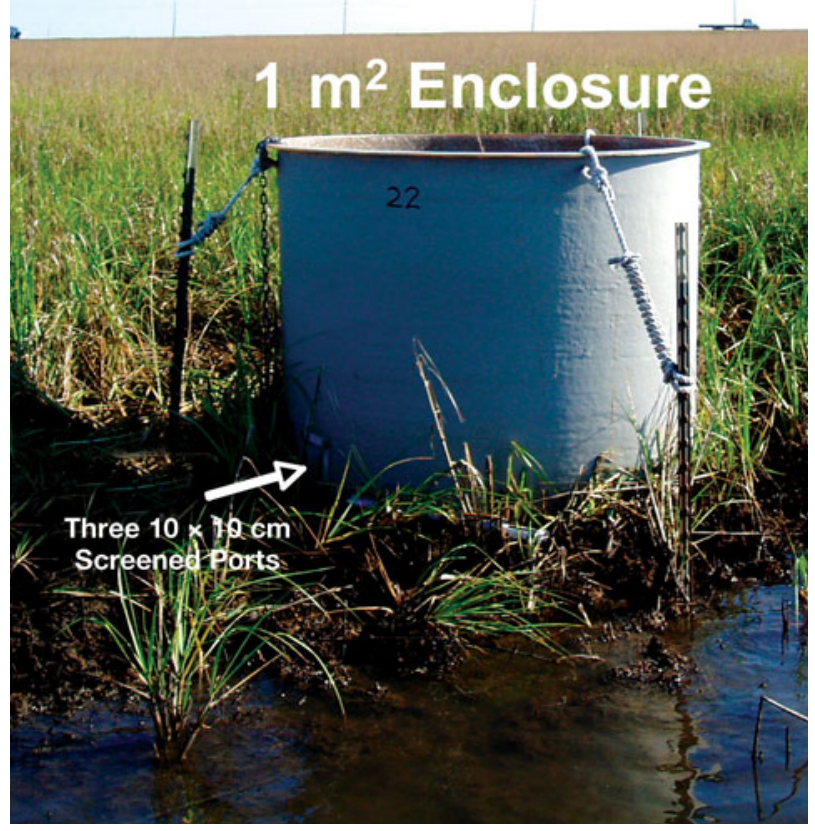

Fig. 1. Mesocosm used for growth experiments. These $1.14 \mathrm{~m}$ diameter fiberglass cylinders were either 1.5 or $1.8 \mathrm{~m}$ tall and enclosed $1 \mathrm{~m}^{2}$ of habitat. Three $10 \times 10 \mathrm{~cm}$ ports covered with $2 \mathrm{~mm}$ mesh screen allowed water exchange between the mesocosm and outside environment 
installed, the bottom edge was pushed about $15 \mathrm{~cm}$ into the substrate, and the mesocosm was anchored in place using metal stakes. When set up in this manner, the mesocosm usually held water even at low tide; the bottom edge of the mesocosm was sealed by the substrate, and the 3 ports were located about $15 \mathrm{~cm}$ above the substrate.

The organisms used in these growth experiments were locally abundant in our estuarine study area (Rozas et al. 2007) when the experiments were initiated. We conducted a total of 2 experiments, one in August 2002 and the second in October 2002, using white shrimp Litopenaeus setiferus, blue crab Callinectes sapidus, and daggerblade grass shrimp Palaemonetes pugio. Two additional experiments were conducted with brown shrimp Farfantepenaeus aztecus, blue crab, and daggerblade grass shrimp in May 2003.

The location of each mesocosm was selected before each experiment using random numbers and a grid placed over an aerial photograph of the study area. Seven replicate mesocosms were placed in each of the 4 habitat types: terrace marsh edge (TerM), reference marsh edge (RefM), terrace pond (TerP), and reference pond (RefP). Mesocosms placed at the marsh edge were located within $1 \mathrm{~m}$ of the shoreline; those placed at pond sites enclosed SNB within $30 \mathrm{~m}$ of the shoreline (terrace marsh or reference marsh). No relationship was detected between growth rate and distance to shore in an analysis of data from Barataria Bay, Louisiana (USA) that compared brown shrimp growth rates among SNB sites located 1, 5, and $20 \mathrm{~m}$ from shore (authors' unpubl. data). In a recent experiment conducted in Galveston Bay, no significant difference was detected in white shrimp growth rates between sites 1 and $30 \mathrm{~m}$ from the marsh shoreline (R. Baker \& T. J. Minello unpubl.).

We used 2 methods to deploy mesocosms. (1) In the first 2 experiments (2002) we attempted to exclude all organisms other than experimental animals from mesocosms by creating a disturbance (splashing, striking the water surface with a paddle) near the site before dropping the mesocosm into place. These attempts were not very successful, because large numbers of animals (not marked experimental organisms) were recovered from enclosures at the termination of the experiments. (2) In the 2 experiments conducted in May 2003 we were careful not to disturb the sites before deploying the mesocosms and attempted to trap and enclose organisms (potential competitors and predators) associated with each habitat type. These mesocosms were dropped into place from a boom attached to a shallow draft boat; this process was similar to that used to deploy enclosure samplers (Zimmerman et al. 1984). Using this second approach, we hoped to incorporate habitat-related competition in our growth measurements and to, therefore, possibly extract the survival rate in addition to the growth rate; these experiments would include not only experimental animals but also a natural complement of enclosed animals. Although these 2 approaches of mesocosm deployment seem quite dissimilar, large numbers of unmarked animals were recovered from enclosures at the termination of all experiments.

On the day an experiment was to be initiated, we collected animals within the study area using small bag seines and immediately transferred them to aerated containers. When enough animals for an experiment had been collected, individuals were tagged, measured to the nearest millimeter (TL: total length for shrimps; CW: carapace width for blue crab), and then assigned randomly to a mesocosm. Five individuals of a species were used per mesocosm in each experiment (except in the May 1, 2003 experiment, in which only 1 blue crab per mesocosm was used). This stocking density (mean $\pm 1 \mathrm{SE}$, individuals per square meter) was within the range of densities for these species (with the exception of grass shrimp) documented from SNB to marsh vegetation (brown shrimp: $2.6 \pm 0.14$ to $10.7 \pm 0.43$, white shrimp: $1.7 \pm 0.18$ to $5.8 \pm 0.51$, blue crab: $1.3 \pm 0.05$ to $6.1 \pm 0.26$ ) in 992 samples collected from the study area between 1982 and 1992 (Rozas et al. 2007). For penaeid shrimps (and for blue crab used in the May 15, 2003 experiment) a relatively large size range of experimental organisms (Table 1) was used to broaden the scope of the results, but it was important to ensure that any relationship between initial size and growth would not be confounding. Therefore these individuals were separated into 5 size categories prior to tagging, and 1 ind. from each size class was placed into each mesocosm. We used Visible Implant Elastomer (VIE) tags to identify each individual penaeid shrimp and blue crab used in the May 15, 2003 experiment. Blue crab used in the other experiments and daggerblade grass shrimp were batch marked (i.e. each animal received the same mark) using VIE tags. We estimated initial weights of experimental animals using length-weight relationships derived from other specimens collected at the beginning of each experiment; this approach was used to reduce handling effects on experimental animals. We derived lengthweight equations by first log transforming the size and weight data to ensure a linear relationship, and then by regressing $\log _{10}$ weight by $\log _{10}$ TL or $\log _{10} \mathrm{CW}$ in regression analyses.

Experimental enclosures restricted animal movement in order to measure habitat-related growth, and we were concerned about effects of enclosures on environmental variables that might affect growth. Salinity, water temperature, dissolved oxygen (DO), and water depth were measured at selected sites 
Table 1. Summary statistics for animals used in the growth experiments. Size range, mean size and 1 standard error (SE), and the total number of animals (n) used in each experiment are shown. Size classes used for each experiment to separate some animals before distributing them among mesocosms also are given

\begin{tabular}{|c|c|c|c|c|c|}
\hline Species & $\begin{array}{l}\text { Size Range } \\
(\mathrm{mm})\end{array}$ & $\begin{array}{l}\text { Mean } \\
(\mathrm{mm})\end{array}$ & $\mathrm{SE}$ & $\mathrm{n}$ & $\begin{array}{l}\text { Size classes } \\
(\mathrm{mm})\end{array}$ \\
\hline \multicolumn{6}{|l|}{ Aug 28-Sep 5, 2002} \\
\hline White shrimp & $23-53$ & 37.4 & 0.67 & 140 & $23-29,30-34,35-39,40-44,45-53$ \\
\hline \multicolumn{6}{|l|}{ Oct $10-17,2002$} \\
\hline White shrimp & $30-69$ & 47.4 & 0.53 & 140 & $30-43,44-45,46-47,48-51,52-69$ \\
\hline Blue crab & $9-26$ & 15.1 & 0.29 & 140 & \\
\hline Daggerblade grass shrimp & $19-27$ & 22.4 & 0.12 & 140 & \\
\hline \multicolumn{6}{|l|}{ May 1-8, 2003} \\
\hline Brown shrimp & $38-60$ & 49.2 & 0.54 & 140 & $38-42,43-46,47-50,51-55,56-60$ \\
\hline Blue crab & $12-25$ & 16.8 & 0.61 & 28 & \\
\hline Daggerblade grass shrimp & $26-28$ & 27.0 & 0.07 & 140 & \\
\hline \multicolumn{6}{|l|}{ May 15-22, 2003} \\
\hline Brown shrimp & $27-51$ & 40.9 & 0.51 & 140 & $27-34,35-39,40-42,43-46,47-51$ \\
\hline Blue crab & $16-40$ & 26.4 & 0.46 & 140 & $16-21,22-24,25-27,28-30,31-40$ \\
\hline
\end{tabular}

inside and outside the mesocosms during the course of each experiment (Table 2). We used a daily monitoring procedure to measure water depth with a meter stick, and water temperature and DO concentration using a handheld meter (YSI); measurements were made 4 to 5 times for each mesocosm. The water depth measured at each mesocosm during daily monitoring was used with continuously recorded water level data from a nearby tide gauge to calculate flooding durations for each experimental site. The other data collected during daily monitoring were used to check the accuracy and assess the reliability of the instruments used to continuously monitor selected mesocosms. Continuous monitoring of selected mesocosms was accomplished using recorders (Onset) to measure water temperature, and Datasonde 3 (Hydrolab) multiparameter water quality loggers for water temperature, salinity, and DO. We also collected a water sample for $\mathrm{NH}_{3}-\mathrm{N}$ analysis from each mesocosm during the May 1, 2003 experiment.

Each growth experiment was run for $\sim 7 \mathrm{~d}$. At the end of an experiment, we used dip nets to collect the animals and then covered the ports and removed the water from inside the mesocosm with a pump; the method was similar to that used to clear a drop sampler (Zimmerman et al. 1984). We immediately placed the animals recovered from the mesocosms on ice and weighed and measured each tagged animal within

Table 2. Methods used to collect environmental data during the growth experiments. Variables measured by each method, sampling frequency, and the number of monitored experimental enclosures are also given. Monitored enclosures are included in the count only if the recorded data were found to be reliable. WTemp $=$ water temperature, $\mathrm{DO}=$ dissolved oxygen, Sal $=$ salinity, WDepth $=$ water depth, TerM $=$ Terrace Marsh, RefM $=$ Reference Marsh, TerP $=$ Terrace Pond, RefP $=$ Reference Pond

\begin{tabular}{|c|c|c|c|c|}
\hline Date of experiment & Method & $\begin{array}{l}\text { Variables } \\
\text { measured }\end{array}$ & $\begin{array}{l}\text { Sampling } \\
\text { frequency }\end{array}$ & $\begin{array}{l}\text { Enclosures } \\
\text { monitored }\end{array}$ \\
\hline Aug 28-Sep 5, 2002 & $\begin{array}{l}\text { Daily monitoring } \\
\text { Temperature loggers } \\
\text { Datasondes }\end{array}$ & $\begin{array}{l}\text { WTemp, DO, WDepth } \\
\text { WTemp } \\
\text { WTemp, DO }\end{array}$ & $\begin{array}{l}\text { Once } \mathrm{d}^{-1} \text { for } 4 \mathrm{~d} \\
\text { Every } 30 \mathrm{~min} \\
\text { Every } 30 \mathrm{~min}\end{array}$ & $\begin{array}{l}\text { All } \\
3 \text { TerM, 2RefM, 2TerP }{ }^{\mathrm{a}}, 2 \operatorname{RefP}^{\mathrm{a}} \\
2^{\mathrm{T} e r M^{\mathrm{a}}}{ }^{2} 2 \operatorname{RefM}^{\mathrm{a}}\end{array}$ \\
\hline Oct $10-17,2002$ & $\begin{array}{l}\text { Daily monitoring } \\
\text { Temperature loggers } \\
\text { Datasondes }\end{array}$ & $\begin{array}{l}\text { WTemp, DO, WDepth } \\
\text { WTemp } \\
\text { WTemp, DO }\end{array}$ & $\begin{array}{l}\text { Once } \mathrm{d}^{-1} \text { for } 4 \mathrm{~d} \\
\text { Every } 30 \mathrm{~min} \\
\text { Every } 30 \mathrm{~min}\end{array}$ & $\begin{array}{l}\text { All } \\
\text { 5TerM, 4RefM, 2TerP, 3RefP } \\
\text { 1TerM, 2RefM }^{\mathrm{a}} \text {, 2TerP, 1RefP }\end{array}$ \\
\hline May 1-8, 2003 & $\begin{array}{l}\text { Daily monitoring } \\
\text { Temperature loggers } \\
\text { Datasondes }\end{array}$ & $\begin{array}{l}\text { WTemp, DO, Sal, WDepth } \\
\text { WTemp } \\
\text { WTemp, DO }\end{array}$ & $\begin{array}{l}\text { Once } \mathrm{d}^{-1} \text { for } 5 \mathrm{~d} \\
\text { Hourly } \\
\text { Hourly }\end{array}$ & $\begin{array}{l}\text { All } \\
\text { 4TerM, 4RefM, 4TerP, 4RefP } \\
\text { 2TerM, 1RefM }\end{array}$ \\
\hline May 15-22, 2003 & $\begin{array}{l}\text { Daily monitoring } \\
\text { Temperature loggers }\end{array}$ & $\begin{array}{l}\text { WTemp, DO, Sal, WDepth } \\
\text { WTemp }\end{array}$ & $\begin{array}{l}\text { Once } d^{-1} \text { for } 5 \mathrm{~d} \\
\text { Hourly }\end{array}$ & $\begin{array}{l}\text { All } \\
\text { 4TerM, 3RefM, 4TerP, 4RefP }\end{array}$ \\
\hline
\end{tabular}


$24 \mathrm{~h}$ to determine their final size. Because TL could not be measured for shrimp with broken rostrums, we estimated the TL of these shrimp based on their final weight from length-weight equations (derived as above for initial lengths). We determined growth rates for each recovered experimental animal by subtracting the initial size measurement (TL, CW or wet weight) from the final size measurement and dividing this difference by the duration (in days) of the experiment.

Data analyses. We considered mean growth rates $\left(\mathrm{mm} \mathrm{d}^{-1}\right.$ or $\left.\mathrm{mg} \mathrm{d}^{-1}\right)$ for a species computed from each mesocosm to be a single observation in our analyses. We used a 1-way ANOVA to test the null hypothesis that growth rates of experimental animals were similar among the 4 habitat types (treatments). In the ANOVA procedure, we analyzed the growth data for each species and experiment separately. If significant at the $\mathrm{p}=0.05$ level, the following treatments were then compared with a priori contrasts: (1) TerM vs. RefP, (2) TerP vs. RefP, and (3) TerM vs. RefM. We selected the first 2 contrasts because terrace marsh and terrace pond are habitat types created from reference (natural) pond habitat when terraces are constructed. The TerM-RefM contrast was used to determine whether growth rates in the created marsh of the terrace field were comparable with those in natural marsh. This same ANOVA model, but with Games-Howell post hoc comparisons, was used to test for differences among treatments in the number of penaeid shrimp recovered from each mesocosm experiment. These unplanned and less powerful comparisons allowed us to compare the recovery of experimental shrimp between all possible treatment pairs.

We used regression analysis to assess potential relationships between brown shrimp growth rates and competitors/predators by comparing growth rates in biomass with penaeid biomass, crustacean biomass, and total biomass measured from both marked and unmarked animals recovered from the experimental mesocosms. We also compared the number of recovered marked shrimp (survivors) with predator biomass to test for a possible relationship between the survival of experimental animals and predator abundance. We also used analysis of covariance (ANCOVA) to assess possible relationships between brown shrimp growth rates and the presence of other animals in the mesocosms. Growth rates from both May 2003 experiments were analyzed together in a 2-way ANCOVA with the log-transformed biomass of all recovered nekton (marked and unmarked) as the covariate in the analysis. We considered alpha levels of 0.05 to be significant in all results. We conducted statistical analyses using SuperANOVA (Version 5, Abacus Concepts) and Microsoft Excel (Version 11.3.7, Microsoft Corporation).

\section{RESULTS}

Tides were relatively high during the experiments, and the pond bottom near each pond mesocosm remained constantly flooded, except at one RefP mesocosm during the May 15, 2003 experiment (Fig. 2). The areas around 3 RefM mesocosms in the October 2002 experiment, all RefM mesocosms in the May experiments, 2 TerM mesocosms in the May 1, 2003 experiment, and all TerM mesocosms in the May 15, 2003 experiment also occasionally drained based on our flooding duration estimates shown in Fig. 2. These flooding durations were calculated for the area just outside each mesocosm, but even when this area drained the area inside each mesocosm usually remained flooded. Our mesocosms were designed to hold water during low water events, because the solid walls were sunken $15 \mathrm{~cm}$ into the substrate to form a seal. The remaining $15 \mathrm{~cm}$ of the solid wall below the screened ports extended above the substrate to retain water for short periods if the water outside drained away. Even so, the integrity of the seal with the sediment was variable, and some mesocosms drained. During the May 15, 2003 experiment, we observed that 2 of the 7 RefM mesocosms drained, and we recovered no live shrimp from these two mesocosms. Marked ani-

White shrimp experiments 2002

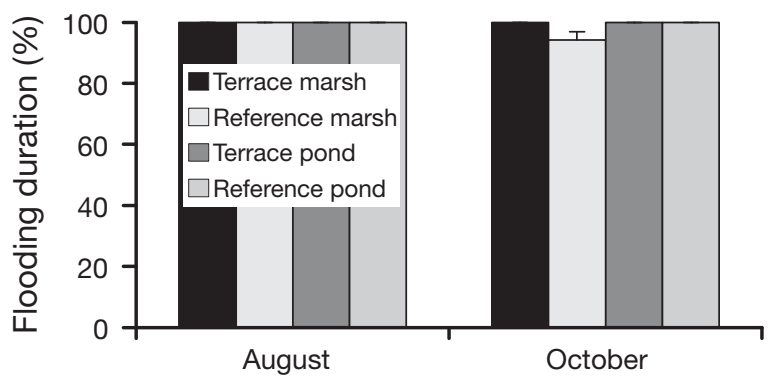

Brown shrimp experiments 2003

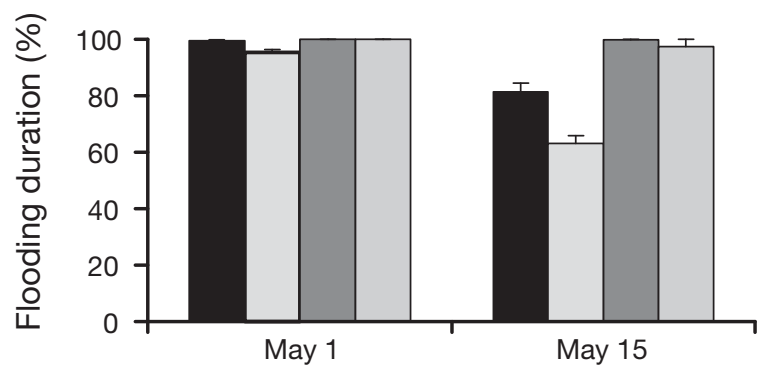

Fig. 2. Average flooding durations [(hours site inundated/ total hours of experiment) $\times 100$ ] of habitat types at mesocosm sites. Means and SEs were calculated from 7 samples from each habitat type 
mals were recovered from all of the other mesocosms listed above that had the area around them drain periodically during the experiments; all of these recovered animals were included in our analyses of growth rates.

Water temperature was measured continuously during all 4 experiments at 9 to 14 selected mesocosms (Table 2). Continuously recorded water temperature data from the Onset recorders were considered reliable, as these data appeared to match the data collected through daily monitoring. Based on these continuous data, highest temperatures occurred during the August 2002 experiments. The range (mean and SE) of temperatures for the August 2002, October 2002, May 1, 2003, and May 15, 2003 experiments were 25.0 to $33.0^{\circ} \mathrm{C}(28.8 \pm 0.04), 14.8$ to $21.8^{\circ} \mathrm{C}(21.8 \pm$ $0.04), 22.5$ to $30.1^{\circ} \mathrm{C}(26.0 \pm 0.02)$, and 20.0 to $35.4^{\circ} \mathrm{C}$ $(27.1 \pm 0.03)$, respectively. During the August 2002 experiment when we continuously monitored water temperature inside and outside 2 pond mesocosms, inside temperatures tracked outside temperatures. Inside temperatures were generally lower than outside temperatures, especially in the afternoon when the temperature peaked each day (Fig. 3). Water temperature varied more at marsh than pond sites over the day, and this diel variation was most pronounced at RefM sites during the May 15, 2003 experiment (Fig. 4).

Salinity and DO data were collected continuously in the August 2002, October 2002, and May 1, 2003 experiments at 4 to 6 selected mesocosms (Table 2). However, several of these records did not match the data we collected from daily monitoring and were discarded as unreliable. Based on the remaining continuous data, salinity ranged from 14.2 to 20.2 (mean $\pm \mathrm{SE}=17.0 \pm$ 0.03) during the August 2002 experiment, 13.5 to 19.6 $(17.9 \pm 0.04)$ during the October 2002 experiment, and 22.5 to $28.0(24.8 \pm 0.09)$ during the May 1, 2003 experiment. Salinity measured inside the experimental mesocosms tracked the salinity measured outside during these experiments (Fig. 5). During the October 2002 experiment, salinity within the terraces appeared less variable than salinity measured outside the terraces in the reference area (Fig. 5).

The range in DO concentration based on the reliable data from continuous measurements was 0.5 to $8.2 \mathrm{mg} \mathrm{l}^{-1}$ $\left(\right.$ mean $\left.\pm \mathrm{SE}=3.8 \pm 0.04 \mathrm{mg} \mathrm{l}^{-1}\right)$ in the August 2002 experiment, 0.8 to $10.1 \mathrm{mg}$ $1^{-1}(4.8 \pm 0.03)$ in the October 2002 experiment, and 1.3 to $9.9 \mathrm{mg} \mathrm{l}^{-1}(5.6 \pm 0.08)$ in the May 1, 2003 experiment. Diel fluctuations were large, with lows in the early morning and highs during the afternoon (Fig. 6). The degree of this daily fluctua- tion in DO varied among experiments. In October 2002, concentrations varied much more at the marsh sites (RefM and TerM) than inside the pond (RefP and TerP) mesocosms. In the May 1, 2003 experiment, DO at the marsh sites exhibited larger daily swings, from lows of 2 to $3 \mathrm{mg} \mathrm{l}^{-1}$ to peaks of 8 to $9 \mathrm{mg} \mathrm{l}^{-1}$. In most comparisons, DO fluctuations inside mesocosms tracked those outside, although overall levels were slightly lower inside for some marsh treatments (Fig. 6).

Concentrations of $\mathrm{NH}_{3}-\mathrm{N}$ in the mesocosms during the May 1, 2003 experiment were low (mean \pm SE: TerM $=0.09 \pm 0.03 \mathrm{mg} \mathrm{l}^{-1}, \operatorname{RefM}=0.11 \pm 0.03 \mathrm{mg} \mathrm{l}^{-1}$, TerP $=0.10 \pm 0.03 \mathrm{mg} \mathrm{l}^{-1}$, RefP $=0.10 \pm 0.02 \mathrm{mg} \mathrm{l}^{-1}$ ). No significant difference in $\mathrm{NH}_{3}-\mathrm{N}$ concentrations among treatments was detected.

Experimental animals ranged in size, but most were small individuals (Table 1). The penaeid shrimps and blue crab used in the experiments were small juveniles ( $<50 \mathrm{~mm}$ mean TL and $<30 \mathrm{~mm}$ mean CW, respectively) that typified the size of animals most abundant in the study area when the experiments were conducted. We used regression analyses to look for an effect of initial size on growth rates in the experiments, but these analyses detected no significant relationship between size and growth rate ( $p>0.07$ and $R^{2}<0.03$ in all cases).

Recovery rates of experimental animals varied by treatment and among the 4 experiments (Fig. 7). Significantly more white shrimp were recovered from RefP and TerP than RefM mesocosms in the August 2002 experiment $($ ANOVA: $\mathrm{MS}=0.522, F=8.768 ; \mathrm{p}=$ 0.0004 , Games-Howell critical difference $=0.355$ and 0.294) and from TerP than RefM and RefP mesocosms in the October 2002 experiment (ANOVA: $\mathrm{MS}=0.286$, $F=7.059 ; \mathrm{p}=0.0015$, Games-Howell critical difference $=0.365$ and 0.147 ). No difference was detected in the

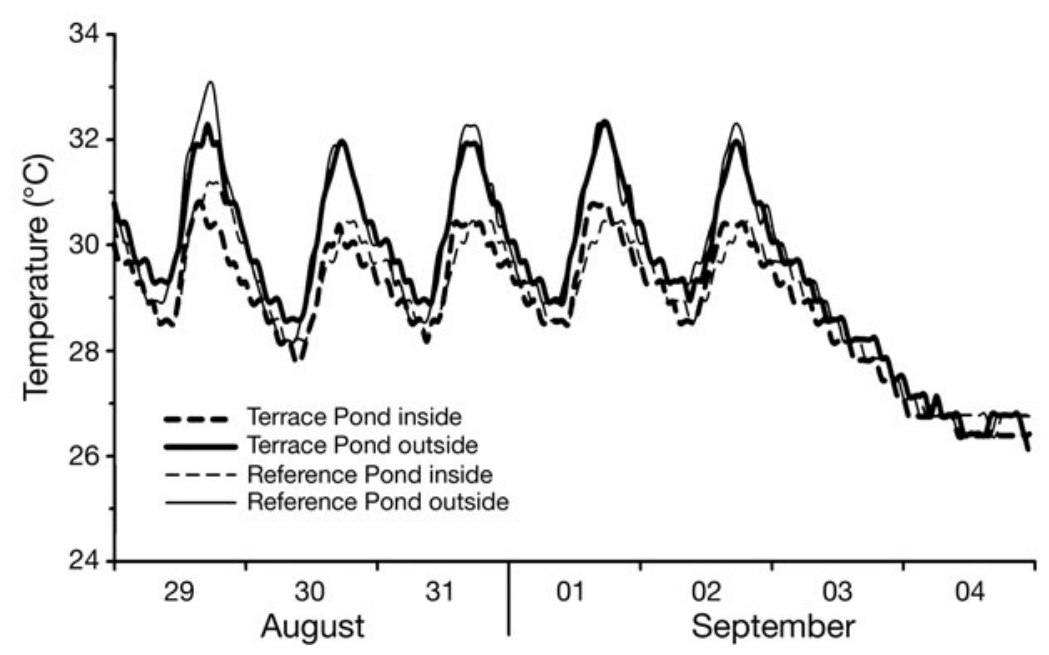

Fig. 3. Comparison of water temperatures measured continuously inside and outside 2 mesocosms during the August 2002 experiment 

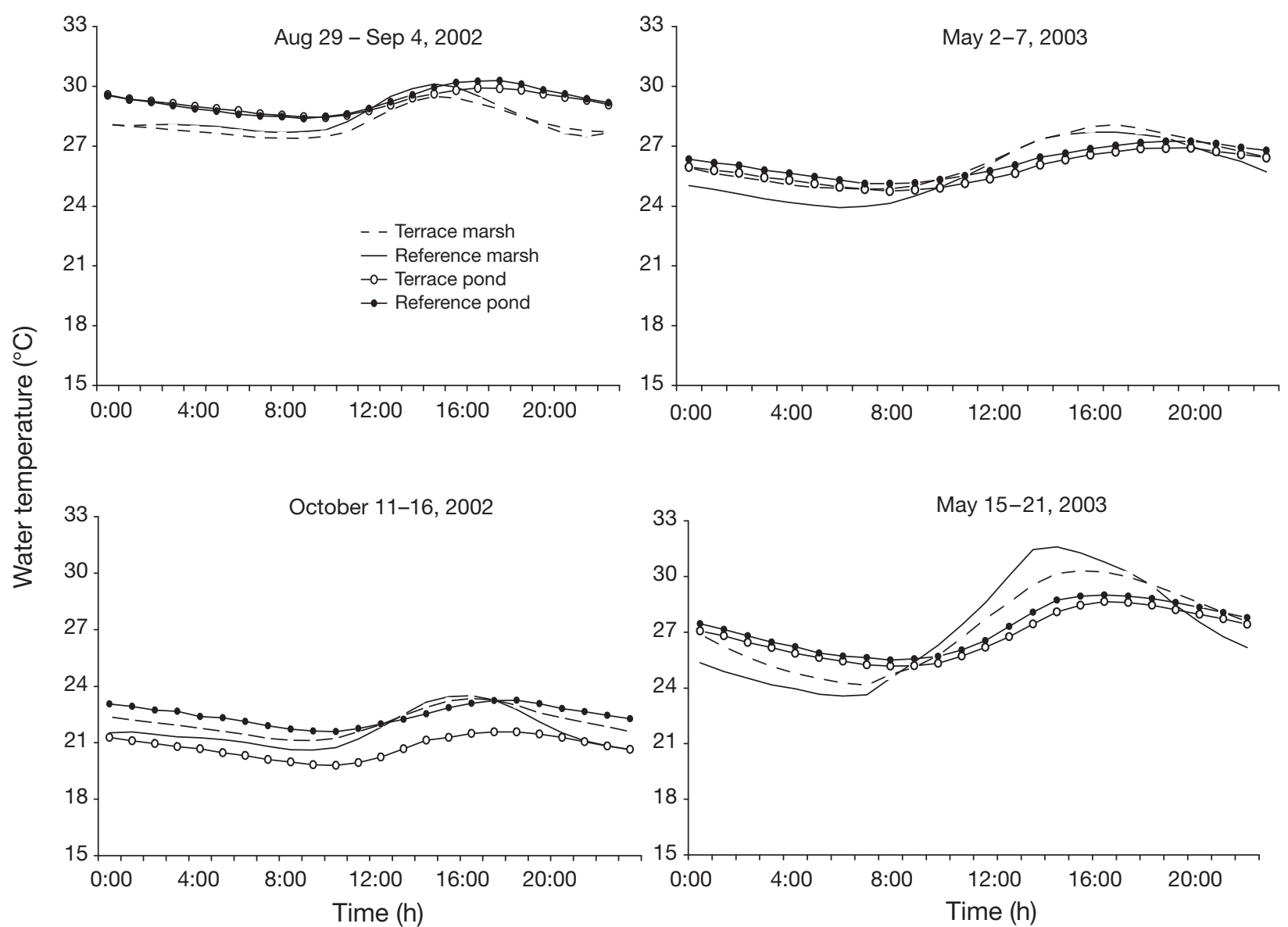

Fig. 4. Average hourly water temperatures within mesocosms calculated for each habitat type over a $24 \mathrm{~h}$ day. Number of instruments used to collect the data from which these means were calculated is given in Table 2

number of brown shrimp recovered among treatments in the May 1, 2003 experiment (ANOVA: MS $=0.027$, $F=0.406, \mathrm{p}=0.7502)$. In the May 15, 2003 experiment, recovery rates were greater in the TerP than RefM mesocosms (ANOVA: $\mathrm{MS}=0.291, F=4.967, \mathrm{p}=$ 0.0080 , Games-Howell critical difference $=0.450$ ).

Mean daily growth rates among treatments in experiments ranged from 0.7 to $1.9 \mathrm{~mm}$ (30 to $143 \mathrm{mg}$ ) for brown shrimp, 0.4 to $1.2 \mathrm{~mm}$ ( 8 to $67 \mathrm{mg}$ ) for white shrimp, 0.3 to $0.6 \mathrm{~mm}$ (15 to $194 \mathrm{mg}$ ) for blue crab, and 0.1 to $0.4 \mathrm{~mm} \mathrm{(0.3} \mathrm{to} 3 \mathrm{mg}$ ) for daggerblade grass shrimp (Table 3 ). These rates differed significantly among experimental treatments for brown shrimp and white shrimp, but no significant difference was detected among treatments for blue crab and daggerblade grass shrimp in any experiment (Table 3 ). In the August 2002 experiment, white shrimp growth rates were greater in TerP than RefP mesocosms (Table 3). Overall, mean white shrimp growth rates were lower in October 2002 than August 2002. No significant difference in growth was detected in October 2002 between the 2 pond treatments, but growth rates were significantly greater in RefP than TerM mesocosms.
Brown shrimp growth rates were significantly greater in RefM than TerM mesocosms in the May 1, 2003 experiment, but no significant difference was detected between these 2 marsh treatments in the May 15, 2003 experiment (Table 3). Growth in the RefP treatment was consistently higher than in the TerM treatment. Reduced growth during the May 15, 2003 experiment in both marsh treatments coincided with reduced flooding duration and relatively low recovery from these mesocosms; there was a significant positive correlation between recovery in a mesocosm and growth in this experiment.

In both May 2003 experiments, we recovered large numbers of unmarked nekton from the experimental mesocosms; these organisms could have affected growth or survival of experimental crustaceans through competition or predation. Potential predators recovered included spot Leiostomus xanthurus, pinfish Lagodon rhomboides, Atlantic croaker Micropogonias undulatus, speckled worm eel Myrophis punctatus, pigfish Orthopristis chrysoptera, red drum Sciaenops ocellatus, silver perch Bairdiella chrysoura, southern flounder Paralichthys lethostigma, and blue crab. 


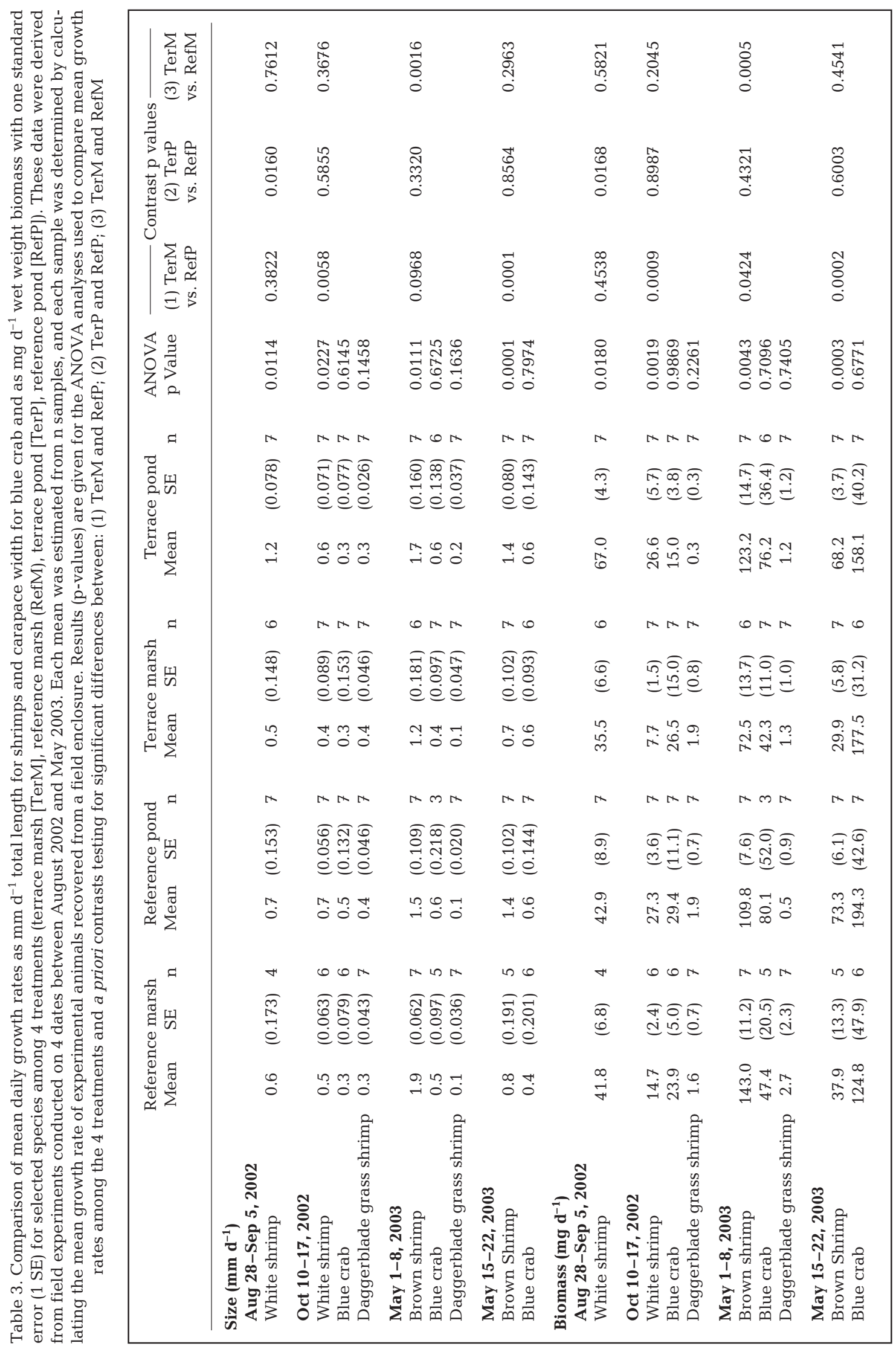



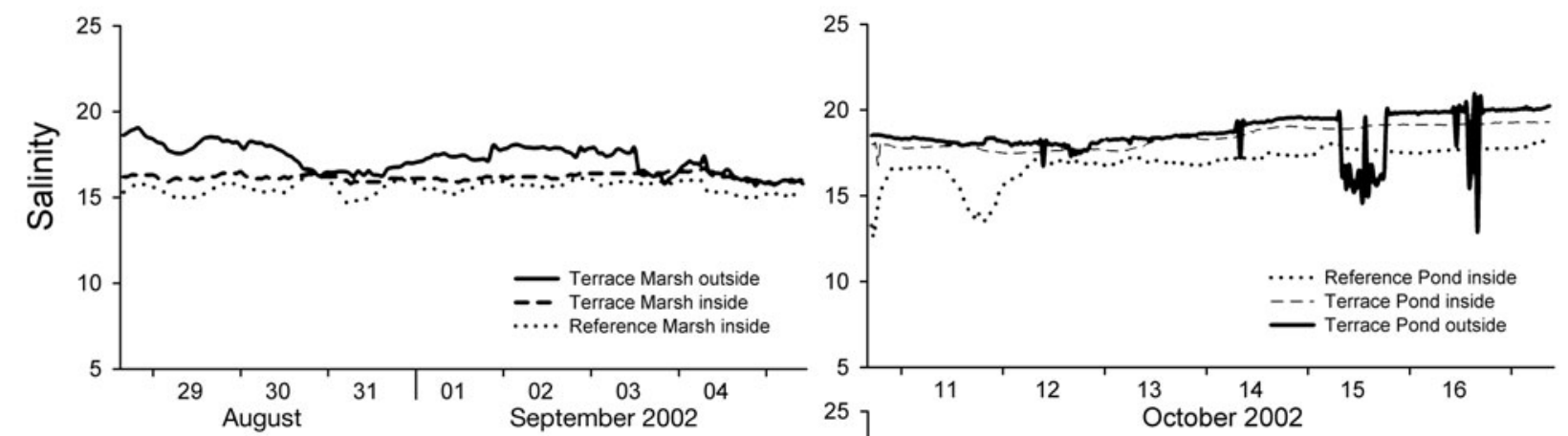

Fig. 5. Comparison of salinity monitored continuously inside and outside selected mesocosms during the August 2002 and October 2002 experiments. Data from terrace marsh (August 2002) and reference marsh (October 2002) were collected inside and outside the same mesocosms
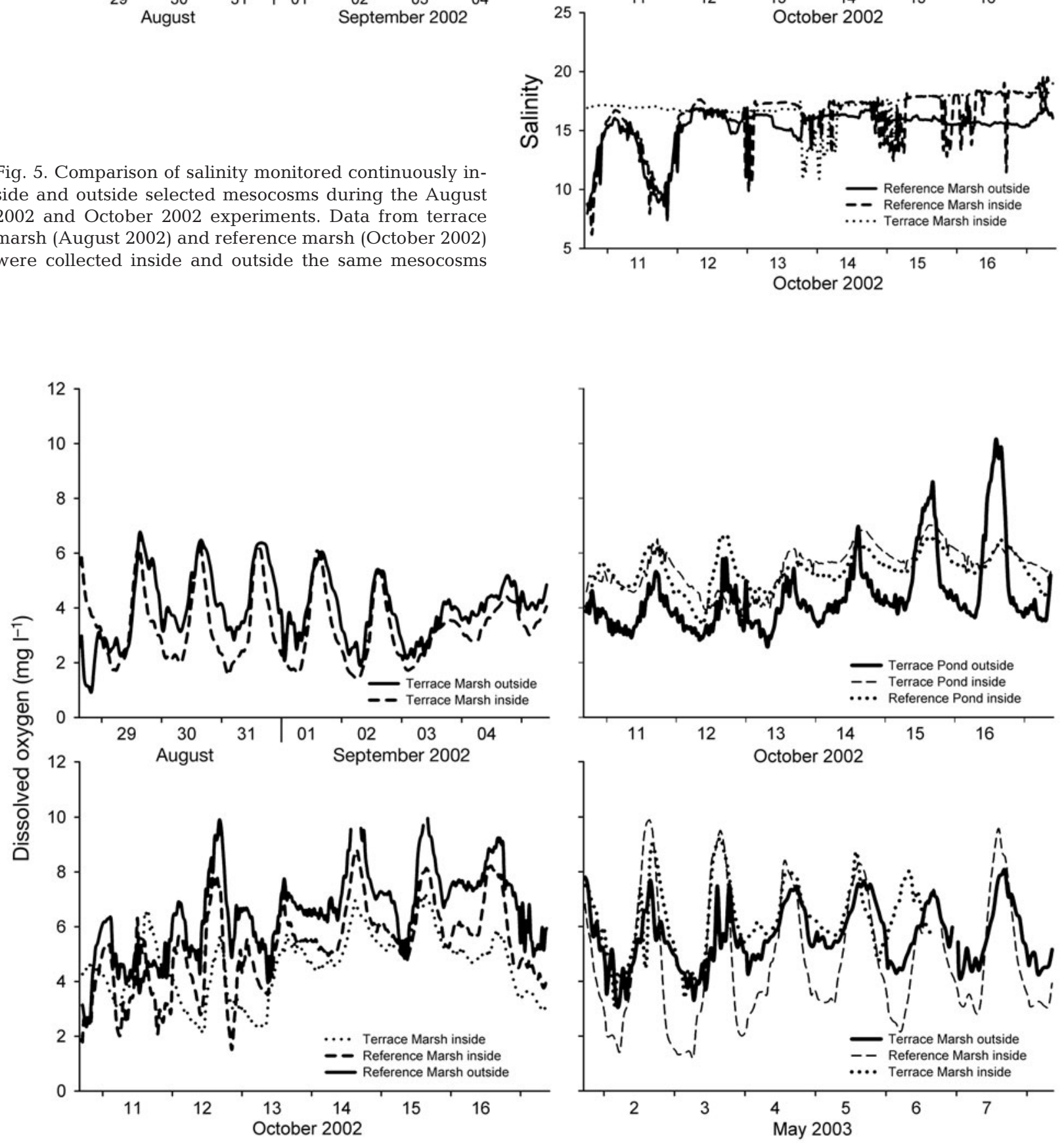

Fig. 6. Comparison of dissolved oxygen concentration monitored continuously inside and outside selected mesocosms during the August 2002, October 2002, and May 1, 2003 experiments. Data from terrace marsh (August 2002) and reference marsh (October 2002) were collected inside and outside the same mesocosms 

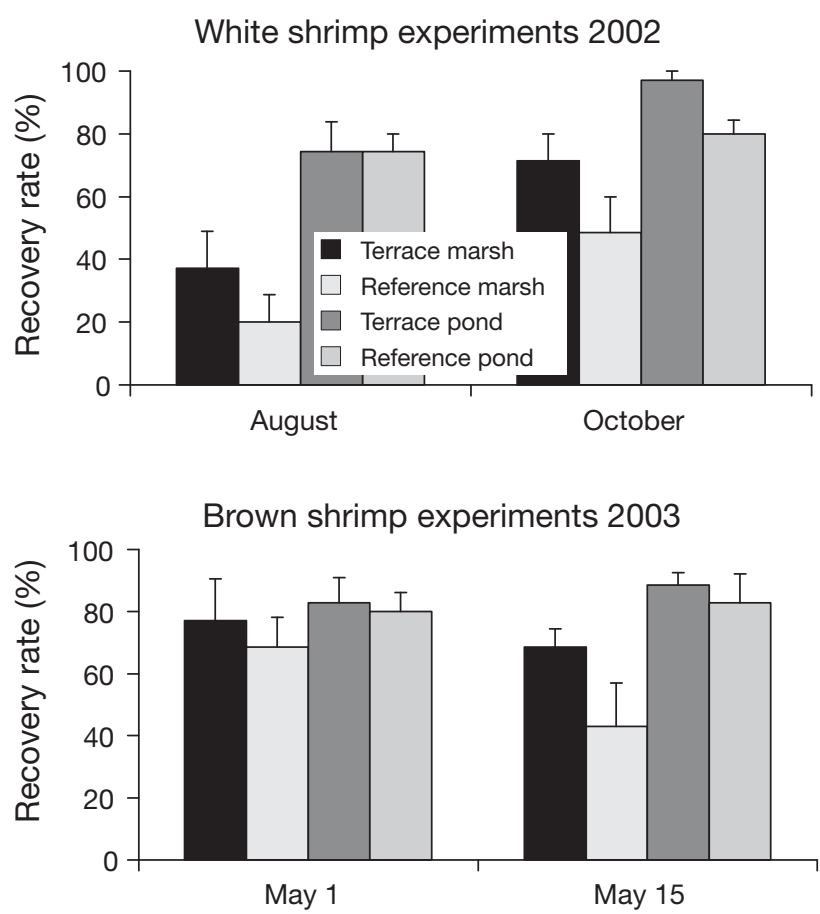

Fig. 7. Comparison among habitat types (terrace marsh, reference marsh, terrace pond, and reference pond) of percentages of penaeid shrimps recovered at the end of growth experiments conducted in 2002 and 2003. Means and standard errors were calculated from 7 samples in each habitat type

Unmarked penaeid shrimps (potential competitors) were also collected from the mesocosms.

There was a significant negative relationship between the biomass of total nekton recovered from enclosures and brown shrimp growth (expressed as biomass increase per day) in the May 2003 experiments. This exponential relationship explained $58 \%$ of the variability in the data (Fig. 8). When both May 2003 experiments were analyzed together in a 2-way ANCOVA with log-transformed biomass of enclosed nekton as the covariate, there was no significant main effect of treatment on growth. However, the interaction term (Treatment $\times$ Experiment) was significant $(p=0.0026)$. The adjusted means showed a pattern similar to the one observed in the initial analysis; shrimp in the May 1, 2003 experiment had relatively high growth rates, with the highest growth being in the RefM and TerP treatments (Fig. 9). In the May 15, 2003 experiment, overall growth was relatively low and there was no significant treatment effect.

Nekton production rates can be estimated for different habitat types using data on density, growth, and survival. Because adequate information on habitatrelated survival is unavailable, we assumed survival to be similar among habitat treatments. We combined

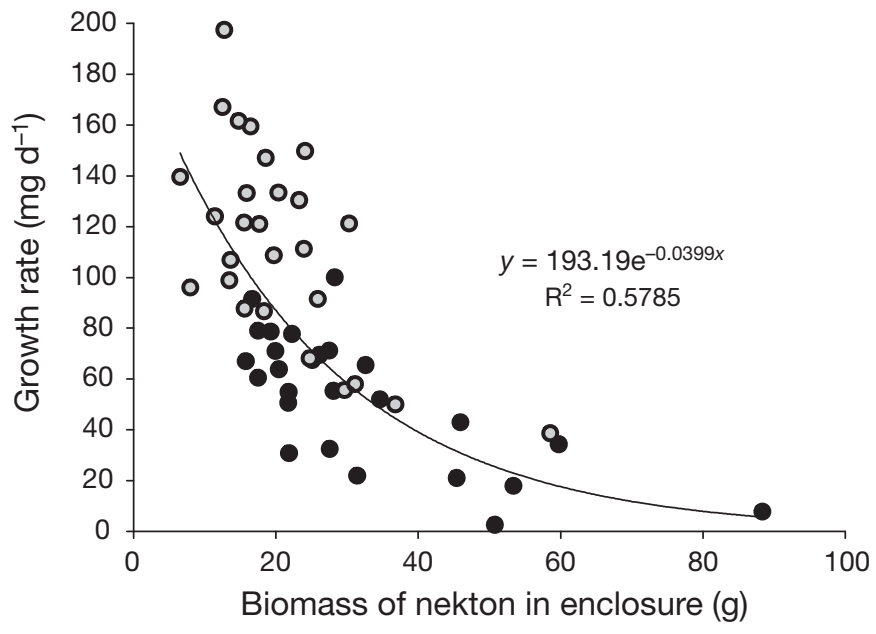

Fig. 8. Relationship between brown shrimp Farfantepenaeus aztecus growth rate and the total biomass of animals recovered from mesocosms in (gray circles) May 1, 2003 and (black circles) May 15, 2003 growth experiments

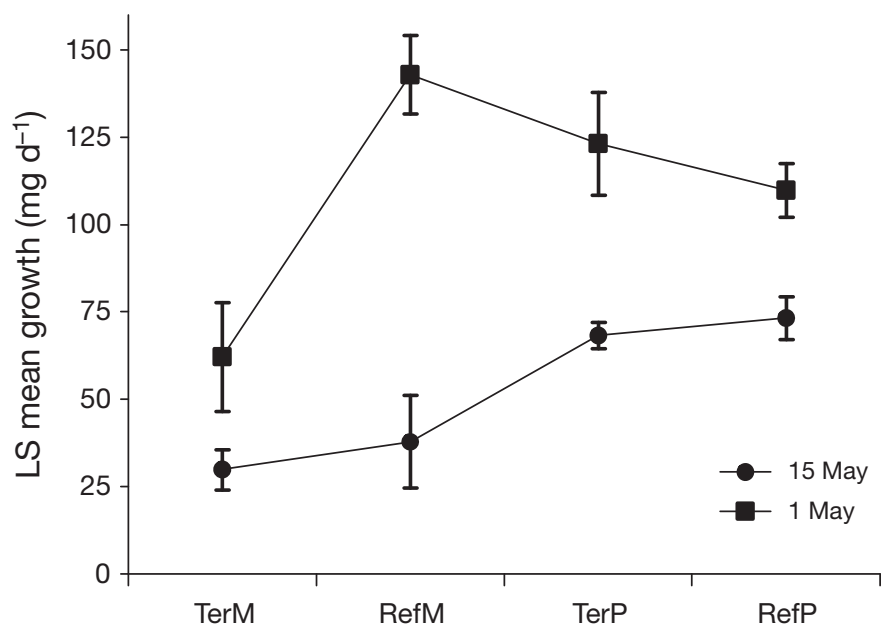

Fig. 9. Comparison of least square (LS) mean growth rates $\left(\mathrm{mg} \mathrm{d}^{-1}\right)$ of brown shrimp Farfantepenaeus aztecus among habitat type treatments terrace marsh (TerM), reference marsh (RefM), terrace pond (TerP), reference pond (RefP), and between experiments (May 1, 2003 and May 15, 2003). The covariate in this analysis was the log-transformed biomass of nekton in experimental enclosures

habitat-related growth rates reported here for brown shrimp, white shrimp, and blue crab with densities for these species reported by Rozas \& Minello (2007). Our objective was to compare nekton production estimates between the terrace field and the reference pond (RefP $=$ the habitat type replaced when terrace projects are constructed). The terrace field was assumed to be made up of $27.6 \%$ TerM, $52.9 \%$ TerP, and $19.5 \%$ borrow area. The proportion for each habitat type used in these calculations was based on the configuration of a 
terrace field composed of medium size cells (Rozas \& Minello 2007). We assumed that growth rates in TerP and borrow area were the same. Using this approach, production rates from the different experiments (estimated as mg of biomass $\mathrm{m}^{-2} \mathrm{~d}^{-1}$ ) appear to be substantially higher in the terrace field than RefP for brown shrimp (224 to 495 vs. 22 to 63), white shrimp (57 to 240 vs. 4 to 26 ), and blue crab (133 to 754 vs. 4 to 55 ).

\section{DISCUSSION}

One objective when constructing marsh terrace fields (TerM and TerP) on SNB (RefP) is to increase production of fishery species such as penaeid shrimps and blue crab. Production is a product of density, mortality, and growth. Previously, we have demonstrated that the density of brown shrimp, white shrimp, and blue crab increases in terrace fields (including those studied here) compared with non-vegetated reference areas (Rozas \& Minello 2001, 2007, Rozas et al. 2005). If growth and survival are higher, or even similar, among these habitats, higher density terrace fields should result in higher production. For example, when we combined the growth rates from the present study with density estimates for these fishery species in our study area, we estimated much higher production rates for a terrace field than for an equal area of RefP (the habitat type replaced by marsh terracing). This comparison of production rates may be conservative because we ignored survival rates in our estimates of production. Survival rates for animals are likely to be higher in the marsh terraces than RefP because the vegetation within terrace fields may afford protection from predators (Minello et al. 2003). However, we do need to be cautious in using these production estimates because mortality rates were not measured, and some habitat types within terrace fields could expose nekton to high mortality rates. For example, borrow areas excavated to construct terrace ridges created areas in the terrace fields $>1 \mathrm{~m}$ deep, and if these relatively deep areas harbor large predators, mortality rates for the young of fishery species within these areas could be relatively high (Rozas et al. 2005). Although borrow areas represent only $\sim 20 \%$ of the terrace fields, high mortality rates there would change our production estimates. We did measure recovery rates, but could not separate the loss of animals due to mortality during the experiments from losses due to inefficiently collecting animals at the end of the experiments.

Our experimental results indicate that there were no strong trends in growth among the habitat types examined. Shallow ponds within the terrace fields (TerP) supported higher growth rates than RefP for white shrimp in the August 2002 experiment, but not in the later October 2002 experiment. Growth rates of blue crab and daggerblade grass shrimp did not differ between terrace and reference habitats. Results for brown shrimp varied between the 2 experiments conducted in May 2003. In early May, shrimp in the reference marsh grew significantly faster than those in the terrace marsh; later in May 2003 mean growth rates were similar between these habitat types, and both were significantly lower than growth on non-vegetated bottom. The biomass of potential competitors for food was substantially higher in marsh habitats, and there was a strong negative relationship between this biomass and brown shrimp growth rates in these May 2003 experiments that explained much of the variability. In both experiments the TerM had the highest nekton biomass, which was substantially higher than the biomass in the RefM or pond treatments. The reduced growth in marsh treatments during the May 15, 2003 experiment also may have been an artifact of the experimental design, because the area surrounding these mesocosms drained for short periods during the experiment, likely causing some physical stress. Such artifacts of the experimental approach are often difficult to detect.

Interacting artifacts are always a concern when conducting field experiments. The mesocosms we used allowed us to measure habitat-specific growth rates by confining experimental animals to specific habitat types. However, restricting these mobile animals to a relatively small area $\left(1 \mathrm{~m}^{2}\right)$ is unnatural and may have affected our results (Stunz et al. 2002). For example, growth rates of experimental animals may have been negatively affected when the DO inside mesocosms occasionally fell to hypoxic levels; in 1 experiment, the animals in 2 mesocosms did not survive because the enclosures drained completely at low tide. Under natural conditions, these animals could have avoided stranding or areas of poor water quality by moving into deeper water. Because the reference area in the present study was adjacent to the terrace fields, unrestrained penaeid shrimp and blue crab could likely have moved among all 4 habitat-type treatments during a tidal cycle. If the recovery of animals from mesocosms is a good indicator of stress and interacting artifacts within enclosures, the May 1, 2003 experiment appeared to exhibit the least potential for artifacts because recovery rates in this experiment were high among all treatments. Growth rates in this experiment were the highest measured, with mean growth in one RefM enclosure reaching as high as $2.1 \mathrm{~mm} \mathrm{~d}^{-1}$.

The differences in growth rates we documented should represent among treatment differences if mesocosm effects were minimal or if such effects were similar among treatments (Peterson \& Black 1994, Underwood 1997, Stunz et al. 2002). We attempted to mini- 
mize potential mesocosm effects by limiting the experimental duration; this reduced the possibility of prey depletion, excessive fouling and excessive sedimentation inside the mesocosms (Sogard 1992, Stunz et al. 2002). Our mesocosm design incorporated ports to facilitate water exchange and equilibrate internal and external environmental conditions. These ports may also allow the entry of potential planktonic prey. We tried to limit stress on experimental animals by minimizing the time between capture and transfer into the mesocosms prior to experimentation. We attempted to match densities of experimental animals to those observed in their natural habitat. The stocking densities for the experimental animals (except grass shrimp) were similar to their mean densities in Spartina edge marsh (brown shrimp: 7.5 ind. $\mathrm{m}^{-2}$, white shrimp: 5.5 ind. $\mathrm{m}^{-2}$, blue crab: 6.2 ind. $\mathrm{m}^{-2}$, daggerblade grass shrimp: 58.8 ind. $\mathrm{m}^{-2}$ ) estimated from a large database of studies from Texas and Louisiana, USA (Minello 1999).

Growth rates of experimental animals in the present study were comparable to those measured under natural conditions (St. Amant et al. 1966, Knudsen et al. 1977, Kneib 1987), and we interpreted this similarity as an indication that mesocosm artifacts were minimal. Mean daily rates for brown shrimp in our experiments were 0.7 to $1.9 \mathrm{~mm} \mathrm{~d}^{-1}$. In a previous experiment conducted in Galveston Bay, brown shrimp held for $27 \mathrm{~d}$ in cages with and without marsh vegetation grew on average 1.0 to $1.4 \mathrm{~mm} \mathrm{~d}^{-1}$ and 0.8 to $1.0 \mathrm{~mm} \mathrm{~d}^{-1}$, respectively (Minello \& Zimmerman 1991). Knudsen et al. (1977) estimated growth rates of 0.5 to $0.9 \mathrm{~mm} \mathrm{~d}^{-1}$ for free ranging brown shrimp in a Louisiana marsh, whereas Wheeler (1969) reported a rate of $1.0 \mathrm{~mm} \mathrm{~d}^{-1}$ for brown shrimp grown in fertilized ponds. St. Amant et al. (1966) related changes in growth rates for free ranging brown shrimp in Louisiana to changes in water temperature and reported average growth rates of $<1.0 \mathrm{~mm} \mathrm{~d}^{-1}$ at $<20^{\circ} \mathrm{C}$ and $<1.5 \mathrm{~mm} \mathrm{~d}^{-1}$ at $<25^{\circ} \mathrm{C}$. A mean growth rate of $1.4 \mathrm{~mm} \mathrm{~d}^{-1}$ was documented for brown shrimp held in acrylic enclosures within a small marsh pond in Louisiana (Fry et al. 2003). Slower rates ( 0.2 to $0.3 \mathrm{~mm} \mathrm{~d}^{-1}$ ) documented for brown shrimp grown in the laboratory on benthic cores extracted from marsh sediment were attributed to food limitation (Whaley 1997, Minello et al. 2003). The mean daily growth rates of 0.4 to $1.2 \mathrm{~mm} \mathrm{~d}^{-1}$ for white shrimp in our experiments are also similar to those documented from previous studies. White shrimp enclosed for $27 \mathrm{~d}$ in cages with and without vegetation in Galveston Bay grew an average of 1.0 and $1.1 \mathrm{~mm} \mathrm{~d}^{-1}$, respectively (Minello \& Zimmerman 1991). White shrimp caged in a shallow non-vegetated pond near Galveston Bay grew an average of $0.8 \mathrm{~mm} \mathrm{~d}^{-1}$ in summer and $0.9 \mathrm{~mm} \mathrm{~d}^{-1}$ in fall (R. Baker \& T. J. Minello unpubl.). More rapid growth rates of 2.1 to $2.3 \mathrm{~mm} \mathrm{~d}^{-1}$ were reported for white shrimp grown in fertilized ponds (Johnson \& Fielding 1956, Wheeler 1969), and slower growth rates for shrimp reared in the laboratory $\left(0.2\right.$ to $0.4 \mathrm{~mm} \mathrm{~d}^{-1}$, Kneib \& Huggler 2001) or caged in marsh vegetation $\left(0.2 \mathrm{~mm} \mathrm{~d}^{-1}\right)$, over SNB $\left(0.3 \mathrm{~mm} \mathrm{~d}^{-1}\right)$, and on oyster reef $\left(0.7 \mathrm{~mm} \mathrm{~d}^{-1}\right)$ at Grand Bay National Estuarine Research Reserve, Mississippi, USA (Shervette \& Gelwick 2008). The mean daily growth rates documented here for blue crab (0.3 to $0.6 \mathrm{~mm} \mathrm{~d}^{-1}$ ) and daggerblade grass shrimp ( 0.1 to $0.4 \mathrm{~mm} \mathrm{~d}^{-1}$ ) were less than the rates for penaeid shrimps, but similar to values reported in the literature for these species (Wood 1967, Tagatz 1968, Leffler 1972, Kneib 1987, Chazaro-Olvera \& Peterson 2004).

The seasonal difference in growth rates we observed is likely to be related to differences in water temperature or food availability. Both mean growth rates of white shrimp and water temperatures were higher during the August 2002 experiment compared to the October 2002 experiment. Penaeid shrimp (Mayer 1985, McTigue \& Zimmerman 1998, Fry et al. 2003, Beseres \& Feller 2007), grass shrimp (Odum \& Heald 1972, Morgan 1980, Kneib 1985), and blue crab (Posey et al. 2005) all feed on shallow-burrowing benthic prey including annelids, small crustaceans, and mollusks. Although food resources were not monitored during our experiments, we assumed that benthic infaunal assemblages would be well established; they develop rapidly in constructed marshes on the northern Gulf of Mexico and are believed to reach parity with natural marshes within a few years (Goldberg 1996, Minello 2000). Our experiments were conducted 3 to $4 \mathrm{yr}$ following the construction of the terracing project, and marsh vegetation (Spartina alterniflora) was well established on the terrace ridges. Benthic infaunal prey populations vary seasonally (Service et al. 1992, Whaley \& Minello 2002), and are generally low in October when we observed lower growth rates for white shrimp. Moreover, predation by white shrimp may play an important role in driving this seasonal decline of benthic infaunal populations within estuaries (Pollack et al. 2009). In retrospect, careful measurements of food availability during the experiments would have helped us interpret the results. Future growth experiments should incorporate measures of food availability. Flooding durations and DO concentrations did not vary substantially between the August 2002 and October 2002 experiments and were unlikely to have affected growth rates.

The vegetation of coastal marshes likely provides a predator refuge for nekton when these marshes are accessible during high tide events (Minello 1993, Heck et al. 2001, Minello et al. 2003). We attempted to assess the refuge value of terrace habitat by comparing survival rates of experimental animals among 
the treatments in May 2003 when the mesocosms were deployed without first disturbing the experimental sites. Our analyses failed to detect any meaningful differences in recovery rates among treatments in the May 2003 experiments, and regression analyses did not detect a significant relationship between the number of surviving shrimp and total predator biomass recovered from mesocosms at the end of an experiment. Recovery rates of experimental animals are not only affected by predation, but also by environmental conditions (water level and water quality) during an experiment and the efficiency of recapturing animals at the end of an experiment. Recovery rates were quite variable among treatments in some experiments and generally higher from pond sites than marsh sites; this is likely because the vegetation at marsh sites interfered with the efficient recapture of animals, but adverse environmental conditions at marsh sites may also have affected these recovery rates. Although we did not observe lengthy periods of hypoxia, not all mesocosms were monitored continuously during experimentation, and poor water quality in some mesocosms may have gone undetected. Low water was a problem in at least 1 experiment: 2 RefM mesocosms drained completely during the May 15, 2003 experiment resulting in the loss of all experimental animals. Undoubtedly, some experimental animals were lost to predation. For example, we collected a red drum (15.3 cm TL) and only two 2 grass shrimp out of a total of 11 marked experimental animals (5 grass shrimp, 5 brown shrimp, 1 blue crab) from a TerM mesocosm at the end of the May 1, 2003 experiment: red drum are known predators of penaeid shrimps, blue crab, and grass shrimp (Bass \& Avault 1975).

We are continuing to explore various means of measuring habitat-related growth. The experimental design and the mesocosms used in the present study had advantages and disadvantages. Because the bottom of the enclosures could be sealed to hold water even at low tide, we could include intertidal marsh in these experiments. Mesocosms could be drained to effectively remove animals by covering the ports and using a trash pump to remove the water. However, the capability of the mesocosms to hold water at low tide was not always reliable, was affected by animal burrows in the sediment, and generally diminished over time during extended periods of low water. Experimental cages often have problems related to clogging of the mesh and possible attraction of prey into the cages through the mesh walls; solid-walled fiberglass mesocosms avoid most of these problems. However, fiberglass mesocosms are heavy and bulky, and transporting large numbers of them to the field is often difficult.
The present study underscores the importance of using multiple metrics to assess the habitat function of restoration projects. Our short-term experiments compared the growth rates of 4 ecologically important decapod crustaceans between marsh terrace habitat and a reference area, yielding mixed results. No difference in growth was detected between terrace habitat and the reference area for blue crab or daggerblade grass shrimp. Brown shrimp and white shrimp occasionally grew more rapidly in the terrace habitat, but this pattern was not consistent. Assessment of the terracing project using only the metric of growth rate was inconclusive. However, when we combined growth rates with densities for brown shrimp and white shrimp measured from the study area and assumed similar mortality rates across habitat types, production rates were substantially higher for terrace fields than SNB (the habitat type replaced when terraces are constructed); the much higher densities of these species in terrace habitat more than compensated for the occasionally slower growth rates there. We do not expect mortality rates for these species to be significantly higher in terrace habitat than SNB. Nonetheless, these production rates should be used with caution because we did not measure mortality rates, which may be relatively high in some habitat types (e.g. borrow areas) of terrace fields. Although mortality rates are relatively difficult to measure, including this metric in future assessments would increase confidence in the results.

Acknowledgements. This research was conducted through the NOAA Fisheries Service Southeast Fisheries Science Center by personnel from the Fishery Ecology Branch (FEB) located at the Galveston Laboratory and the Estuarine Habitats and Coastal Fisheries Center in Lafayette, Louisiana. The assistance of everyone in the FEB was essential for the successful completion of this project. In particular, we thank H. Clinton, M. Dillender, J. Ditty, J. Doerr, S. Hillen, J. Kernan, K. Kilfoyle, G. Miller, F. Nix, M. Prine, J. Salas, K. Turner, $\mathrm{K}$. Williams, and E. Wilson for helping to collect and process samples. P. Caldwell constructed Fig. 1 and M. Kimball Figs. 3, 5 and 6. R. Baker provided assistance in the data analysis. We acknowledge the NOAA Restoration Center and NOAA Fisheries Service Southeast Fisheries Science Center for funding this research project. We thank 2 anonymous reviewers who offered suggestions that improved the original manuscript. The findings and conclusions in this report are those of the authors and do not necessarily represent the views of the NOAA Fisheries Service.

\section{LITERATURE CITED}

Bagenal TB (1978) Aspects of fish fecundity. In: Gerking SD (ed) Ecology of freshwater fish production. Wiley, New York, p 75-101

> Bass RJ, Avault JW Jr (1975) Food habits, length-weight relationship, condition factor, and growth of juvenile red drum, Sciaenops ocellata, in Louisiana. Trans Am Fish Soc 104:35-45 
Beck MW, Heck KL, Able KW, Childers DL and others (2001) The identification, conservation, and management of estuarine and marine nurseries for fish and invertebrates. BioScience 51:633-641

Beseres JJ, Feller RJ (2007) Importance of predation by white shrimp Litopenaeus setiferus on estuarine subtidal macrobenthos. J Exp Mar Biol Ecol 344:193-205

Bush Thom CS, La Peyre MKG, Nyman JA (2004) Evaluation of nekton use and habitat characteristics of restored Louisiana marsh. Ecol Eng 23:63-75

Chazaro-Olvera S, Peterson MS (2004) Effects of salinity on growth and molting of sympatric Callinectes spp. from Camaronera Lagoon, Veracruz, Mexico. Bull Mar Sci 74: 115-127

Fry B, Baltz DM, Benfield MC, Fleeger JW, Gace A, Haas HL, Quiñones-Rivera ZJ (2003) Stable isotope indicators of movement and resiliency for brown shrimp (Farfantepenaeus aztecus) in coastal Louisiana marshscapes. Estuaries 26:82-97

Goldberg AR (1996) Development of infaunal populations and below-ground organic matter from three created Spartina alterniflora marshes in Galveston Bay, Texas. MS thesis, Texas A \& M University, College Station, TX

Gossman BP (2005) Use of terraced marsh habitats by estuarine nekton in southwestern Louisiana. MS thesis, Louisiana State University, Baton Rouge, LA

> Heck KL Jr, Coen LD, Morgan SG (2001) Pre- and post-settlement factors as determinants of juvenile blue crab Callinectes sapidus abundance: results from the north-central Gulf of Mexico fishery. Mar Ecol Prog Ser 222:163-176

Houde ED (1987) Fish early life dynamics and recruitment variability. Am Fish Soc Symp 2:17-29

Houde ED (1989) Subtleties and episodes in the early life of fishes. J Fish Biol 35:29-38

Johnson MC, Fielding JR (1956) Propagation of the white shrimp, Penaeus setiferus (Linn.) in captivity. Tulane Stud Zool 4:175-190

Kneib RT (1985) Predation and disturbance by grass shrimp, Palaemonetes pugio Holthuis, in soft-substratum benthic invertebrate assemblages. J Exp Mar Biol Ecol 93:91-102

Kneib RT (1987) Seasonal abundance, distribution and growth of postlarval and juvenile grass shrimp (Palaemonetes pugio) in a Georgia, USA, salt marsh. Mar Biol 96: 215-223

Kneib RT, Huggler MC (2001) Tag placement, mark retention, survival and growth of juvenile white shrimp (Litopenaeus setiferus Perez Farfante, 1969) injected with coded wire tags. J Exp Mar Biol Ecol 266:109-120

Knudsen EE, Herke WH, Mackler JM (1977) The growth rate of marked juvenile brown shrimp, Penaeus aztecus, in a semi-impounded Louisiana coastal marsh. Proc Gulf Caribb Fish Inst 29:144-159

La Peyre M, Gossman B, Nyman J (2007) Assessing functional equivalency of nekton habitat in enhanced habitats: comparison of terraced and unterraced marsh ponds. Estuaries Coasts 30:526-536

Leffler CW (1972) Some effects of temperature on the growth and metabolic rate of juvenile blue crabs, Callinectes sapidus, in the laboratory. Mar Biol 14:104-110

Levin P, Petrik R, Malone J (1997) Interactive effects of habitat selection, food supply and predation on recruitment of an estuarine fish. Oecologia 112:55-63

Mayer MA (1985) Ecology of juvenile white shrimp, Penaeus setiferus Linnaeus, in the salt marsh habitat. MS thesis, Georgia Institute of Technology, Atlanta, GA

McTigue TA, Zimmerman RJ (1998) The use of infauna by juvenile Penaeus aztecus Ives and Penaeus setiferus (Linnaeus). Estuaries 21:160-175
Minello TJ (1993) Chronographic tethering: a technique for measuring prey survival time and testing predation pressure in aquatic habitats. Mar Ecol Prog Ser 101:99-104

Minello TJ (1999) Nekton densities in shallow estuarine habitats of Texas and Louisiana and the identification of essential fish habitat. In: Benaka L (ed) Fish habitat: essential fish habitat and habitat rehabilitation. Amer Fish Soc Symp 22:43-75

Minello TJ (2000) Temporal development of salt marsh value for nekton and epifauna: utilization of dredged material marshes in Galveston Bay, Texas, USA. Wetlands Ecol Manage 8:327-341

Minello TJ, Zimmerman RJ (1991) The role of estuarine habitats in regulating growth and survival of juvenile penaeid shrimp. In: DeLoach P, Dougherty WJ, Davidson MA (eds) Frontiers in shrimp research. Elsevier Science Publishers, Amsterdam, p 1-16

> Minello TJ, Able KW, Weinstein MP, Hays CG (2003) Salt marshes as nurseries for nekton: testing hypotheses on density, growth and survival through meta-analysis. Mar Ecol Prog Ser 246:39-59

Morgan MD (1980) Grazing and predation of the grass shrimp Palaemonetes pugio. Limnol Oceanogr 25:896-902

Moyle PB, Cech JJ Jr (1982) Fishes: an introduction to ichthyology. Prentice-Hall, Englewood Cliffs, NJ

Odum WE, Heald EJ (1972) Trophic analysis of an estuarine mangrove community. Bull Mar Sci 22:671-738

Orlando SP Jr, Rozas LP, Ward GH, Klein CJ (1991) Analysis of salinity structure and stability for Texas estuaries. Strategic Assessments Branch, NOS/NOAA, Rockville, MD

Peterson CH, Black R (1994) An experimentalist's challenge: when artifacts of intervention interact with treatments. Mar Ecol Prog Ser 111:289-297

Phelan BA, Goldberg R, Bejda AJ, Pereira J, and others (2000) Estuarine and habitat-related differences in growth rates of young-of-the-year winter flounder (Pseudopleuronectes americanus) and tautog (Tautoga onitis) in three northeastern US estuaries. J Exp Mar Biol Ecol 247:1-28

> Beseres Pollack JB, Buzzelli CP, Feller RJ (2009) The predator role of white shrimp (Litopenaeus setiferus) in seasonal declines of subtidal macrobenthos. Hydrobiologia 627: $117-128$

> Posey MH, Alphin TD, Harwell H, Allen B (2005) Importance of low salinity areas for juvenile blue crabs, Callinectes sapidus Rathbun, in river-dominated estuaries of southeastern United States. J Exp Mar Biol Ecol 319:81-100

Rooker JR, Holt SA, Holt GJ, Fuiman LA (1999) Spatial and temporal variability in growth, mortality, and recruitment potential of postsettlement red drum, Sciaenops ocellatus, in a subtropical estuary. Fish Bull (Wash DC) 97:581-590

Rozas LP, Minello TJ (2001) Marsh terracing as a wetland restoration tool for creating fishery habitat. Wetlands 21: $327-341$

Rozas LP, Minello TJ (2007) Restoring coastal habitat using marsh terracing: the effect of cell size on nekton use. Wetlands 27:595-609

Rozas LP, Caldwell P, Minello TJ (2005) The fishery value of salt marsh restoration projects. J Coast Res 40(Spec Issue):37-50

Rozas LP, Minello TJ, Zimmerman RJ, Caldwell P (2007) Nekton populations, long-term wetland loss, and the effect of recent habitat restoration in Galveston Bay, TX (USA). Mar Ecol Prog Ser 344:119-130

> Service SK, Feller RJ, Coull BC, Woods R (1992) Predation effect of three fish species and a shrimp on macrobenthos and meiobenthos in microcosms. Estuar Coast Shelf Sci $34: 277-293$ 
Shervette VR, Gelwick F (2008) Relative nursery function of oyster, vegetated marsh edge, and nonvegetated bottom habitats for juvenile white shrimp Litopenaeus setiferus. Wetlands Ecol Manage 16:405-419

Sogard SM (1992) Variability in growth rates of juvenile fishes in different estuarine habitats. Mar Ecol Prog Ser 85: 35-53

St. Amant LS, Broom JG, Ford TB (1966) Studies of the brown shrimp, Penaeus aztecus, in Barataria Bay, Louisiana, 1962-1965. Proc Gulf Caribb Fish Inst 18:1-17

Stunz GW, Minello TJ, Levin PS (2002) Growth of newly settled red drum Sciaenops ocellatus in different estuarine habitat types. Mar Ecol Prog Ser 238:227-236

Tagatz ME (1968) Growth of juvenile blue crabs, Callinectes sapidus Rathbun, in the St. Johns River, Florida. Fish Bull (Wash D C) 67:281-288

Turner RE, Streever B (2002) Approaches to coastal wetland restoration: northern Gulf of Mexico. SPB Academic Publishing, The Hague

Underwood AJ (1997) Experiments in ecology: their logical design and interpretation using analysis of variance. Cambridge University Press, Cambridge

Underwood SG, Steyer GD, Good B, Chambers D (1991) Bay

Editorial responsibility: Kenneth Heck,

Dauphin Island, Alabama, USA bottom terracing and vegetative planting: an innovative approach for habitat and water quality enhancement. In: Webb FJ Jr (ed) Annual conference on wetlands restoration and creation. Hillsborough Community College, Tampa, FL, p 164-173

Whaley SD (1997) The effects of marsh edge and surface elevation on the distribution of salt marsh infauna and prey availability for nekton predators. MSc thesis, Texas A \& M University, College Station, TX

Whaley SD, Minello TJ (2002) The distribution of benthic infauna of a Texas salt marsh in relation to the marsh edge. Wetlands 22:753-766

Wheeler RS (1969) Culture of penaeid shrimp in brackishwater ponds, 1966-67. Proc SE Assoc Game Fish Comm 22:387-391

Wood CE (1967) Physioecology of the grass shrimp Palaemonetes pugio, in the Galveston Bay estuarine system. Contrib Mar Sci 12:54-79

Zimmerman RJ, Minello TJ, Zamora G (1984) Selection of vegetated habitat by brown shrimp, Penaeus aztecus, in a Galveston Bay salt marsh. Fish Bull (Wash DC) 82: 325-336

Submitted: March 4, 2009; Accepted: August 14, 2009 Proofs received from author(s): November 11, 2009 